\title{
La percepción de las familias ante la animación hospitalaria: estudio realizado en el hospital Materno-Infantil de Oviedo

\author{
Familys' Perception of Hospital Animation: A case study carried \\ out at Hospital Materno-Infantil in Oviedo (Spain) \\ Percepção Familys 'Hospital de Animação: Um estudo de caso \\ realizado no Hospital Materno-Infantil em Oviedo (Espanha)
}

M. Teresa Bermúdez Rey y Susana Torío López

UNIVERSIDAD DE OVIEDO

Resumen

En estas líneas se recoge parte de una investigación financiada por la Universidad de Oviedo, sobre la animación realizada en las plantas de Pediatría del Hospital MaternoInfantil de la capital asturiana.

La animación hospitalaria es llevada a cabo por asociaciones de voluntariado de reconocida trayectoria: CRUZ ROJA, GALBÁN, (que realiza solo animación con pacientes pediátricos oncológicos), Voluntariado de la Fundación "La Caixa" (que abre las puertas de las ciber@ulas a todos los niños ingresados en el centro sanitario) y SED (Solidaridad, Educación y Desarrollo).

En concreto se hace referencia a la opinión de los padres de niños hospitalizados sobre el empleo del tiempo libre de los enfermos, en el que se recogían aspectos como la ocupación del paciente en el tiempo libre; con quién lo comparte; el lugar de juego; la influencia, dedicación y relación con el voluntariado; los efectos que la animación

\section{Abstract}

This paper collects part of a research project sponsored by the University of Oviedo on the animation carried out in the Paediatrics Ward at the Materno-Infantil Hospital of the Asturian capital city, by the following well-known NGO's: Cruz Roja, Galbán, which only works with paediatric patients with cancer, Volunteers of "La Caixa” Foundation, which open their cyberclassrooms to all the children who are in hospital, and SED -Solidarity, Education and Development.

We refer particularly to a survey addressed to those parents whose children were hospitalized regarding the use of those patients' free time and which included other features such as use of free time, people it is shared with, influence, dedication and relationship with volunteers, effects of animation on patients, parents and their siblings -if animation was extended to them- as well as the physical

LA PERCEPCIÓN DE LAS FAMILIAS ANTE LA ANIMACIÓN HOSPITALARIA... [ 223 ] SIPS - REVISTA INTERUNIVERSITARIA DE PEDAGOGIA SOCIAL[1139-1723 (2012) 20, 223-242] TERCERA EPOCA 
tiene sobre los enfermos y las familias; la existencia de animación con los hermanos del paciente pediátrico; así como las características físicas que a su juicio, debieran reunir tanto el hospital como las habitaciones de los enfermos.

El análisis del estudio permite identificar la gran aceptación que los padres de los pacientes pediátricos muestran, con respecto a la animación hospitalaria llevada a cabo en el hospital por las cuatro asociaciones antes mencionadas, y pone de manifiesto las consecuencias positivas derivadas de la realización de la misma.

Estos resultados avalan la necesidad de profesionalizar la animación hospitalaria, sin que ello suponga prescindir de las valiosas aportaciones del voluntariado. En consonancia con lo anterior, se trazan unas líneas generales de actuación

PALABRAS CLAVE: animación hospitalaria, paciente, pediatría, profesionalización, padres y madres, voluntariado.

\section{Resumo}

Este artigo recolhe parte de um projeto de pesquisa patrocinado pela Universidade de Oviedo sobre a animação realizado na Ala de Pediatria do Hospital Materno-Infantil da capital das Astúrias cidade, pelo conhecido ONGs: Cruz Roja, Galbán, que só trabalha com pacientes com câncer de pediatria, voluntários da Fundação Caixa, que abre suas ciber-salas de aula para todas as crianças que estão no hospital, e SEDSolidariedade, Educação e Desenvolvimento.

Nós, particularmente, referem-se a um inquérito dirigido a pais cujos filhos estavam no hospital sobre o uso do tempo livre desses pacientes e que inclui outras características tais como o uso de tempo livre, as pessoas que compartilham com ele, influência, dedicação e relacionamento com voluntários, efeitos de animação para os doentes, os pais e seus irmãos-se animação foi estendida a eles, bem features which should be considered in those hospitals and wards.

The descriptive, exploratory and explanatory analysis of the study lets us identify the great approval of parents in reference to the hospital animation carried out by the above mentioned NGO's and points out its positive consequences.

These results support the necessity to professionalize hospital animation, which does not mean disregarding the volunteers' valuable contribution. General lines of action are laid out in accordance with these findings.

KEY WORDS: hospital animation, patient, paediatrics, professionalization, parents and mothers, volunteers.

\section{Resumo}

Este artigo recolhe parte de um projeto de pesquisa patrocinado pela Universidade de Oviedo sobre a animação realizado na Ala de Pediatria do Hospital Materno-Infantil da capital das Astúrias cidade, pelo conhecido ONGs: Cruz Roja, Galbán, que só trabalha com pacientes com câncer de pediatria, voluntários da Fundação Caixa, que abre suas ciber-salas de aula para todas as crianças que estão no hospital, e SEDSolidariedade, Educação e Desenvolvimento.

Nós, particularmente, referem-se a um inquérito dirigido a pais cujos filhos estavam no hospital sobre o uso do tempo livre desses pacientes e que inclui outras características tais como o uso de tempo livre, as pessoas que compartilham com ele, influência, dedicação e relacionamento com voluntários, efeitos de animação para os doentes, os pais e seus irmãos-se animação foi estendida a eles, bem 
como as características físicas que os hospitais e as enfermarias devem cumprir.

A análise descritiva, exploratória e explicativa do estudo nos permite identificar a aprovação grande mostrada pelos pais da animação hospitalar realizado pela referida ONG e aponta suas conseqüências positivas.

Estes resultados suportam a necessidade de profissionalizar a animação hospital, o que não significa desconsiderar a contribuição dos voluntários valioso. Em conformidade, as linhas gerais de ação são definidos.

PALAVRAS-CHAVE: animação hospital, o paciente, pediatria, profissionalização, os pais e mães, voluntários.

\section{Introducción}

Es sabido que la enfermedad del niño hospitalizado incide en el bienestar psicológico del paciente y de su familia; en los padres se observan cambios en el rol parental, preocupaciones relacionadas con la alteración de la rutina diaria, ansiedad causada por el comportamiento del niño o niña, trato con el personal sanitario y preocupaciones sobre la enfermedad y los procedimientos médicos que se suelen traducir en estrés, depresión y cansancio (Palomo, 1995; Quiles y Pedroche, 2000). El paciente pediátrico ve alterado su ritmo de vida, además de acompañar su comportamiento de ansiedad, depresión, trastornos de sueño y dificultades en el contacto social (Serradas, Ortiz y Manueles, 2002). Si nos detenemos a pensar en el ritmo de vida que se le impone a un paciente en el hospital difiere totalmente del que lleva en su casa. Ha abandonado el medio natural en el que se desenvuelve, su familia y amigos para entrar en un universo nuevo en el que todo es distinto, tanto el medio que le rodea (habitaciones, pasillos, rigidez en el horario, falta de espacio...) como las personas con las que tiene que relacionarse (médicos, enfermeras, otros pacientes, etc..). Se trata de lograr, por tanto, como as características físicas que os hospitais e as enfermarias devem cumprir.

A análise descritiva, exploratória e explicativa do estudo nos permite identificar a aprovação grande mostrada pelos pais da animação hospitalar realizado pela referida ONG e aponta suas conseqüências positivas.

Estes resultados suportam a necessidade de profissionalizar a animação hospital, o que não significa desconsiderar a contribuição dos voluntários valioso. Em conformidade, as linhas gerais de ação são definidos.

PALAVRAS-CHAVE: animação hospital, o paciente, pediatria, profissionalização, os pais e mães, voluntários.

\section{Introduction}

It is widely known that the illness of a hospitalized child has a direct bearing on the psychological well-being of the patients and their families. Parental role changes, worries related to alterations in daily routines, anxiety caused by the child's behaviour, stress, depression and fatigue brought on from dealing with the medical staff, may be observed in the parents (Palomo, 1995; Quiles \& Pedroche, 2000). The paediatric patient's pace of life is altered, as well as having anxiety, depression, sleep disorders and difficulties with social contact (Serradas, Ortiz \& Manueles, 2002). If the pace of life imposed on a hospitalized patient is considered, it may be observed that it is completely different from that of a person in their home. They have left behind not only the natural habitat in which they carry out their daily routines, but also their family and friends to enter a new universe in which everything is different, not only the surrounding habitat (rooms, hallways, strict timetable, lack of personal space) but also the people which must be dealt with (doctors, nurses, other patients, etc....). It is a question of achieving, then, that the 
para que la hospitalización sea lo menos traumatizante posible, que el paciente, y en especial, los niños y niñas, puedan llevar una vida semejante a la de su medio ambiente habitual (Cárdenas y López, 2005-2006; López y Fernández, 2006).

La investigación de los últimos años se orientó hacia la búsqueda de soluciones que pudieran paliar los efectos de dicha hospitalización; en esta línea y en el año 1986, el Parlamento Europeo a través de la Resolución del 13 de mayo, hizo pública "La Carta Europea de los Derechos de los niños hospitalizados" (http//www.secp.org), entre los que destacamos los siguientes apartados:

- Derecho de los niños a disponer de lugares amueblados y equipados de modo que respondan a sus necesidades en materia de cuidados, educación y de juegos, así como a las normas oficiales de seguridad.

- Derecho a proseguir la formación escolar durante su permanencia en el hospital, y a beneficiarse de las enseñanzas de maestros y del material didáctico que las autoridades escolares pongan a su disposición, en particular en el caso de una hospitalización prolongada, con la condición de que dicha actividad no cause perjuicios a su bienestar y/o que no obstaculice los tratamientos que se siguen.

- Derecho a disponer, durante su permanencia en el hospital de juguetes, libros y medios audiovisuales adecuados a su edad.

- Derecho a poder recibir estudios en caso de hospitalización parcial o de convalecencia en su propio domicilio.

En los últimos años se han introducido de forma paulatina en clínicas y centros hospitalarios de diversos países y, también en España, profesionales de la educación quienes intentan cubrir las necesidades psicopedagógicas de las niñas y niños hospitalizados y dar una atención de calidad a sus familias, hospitalization be the least traumatic possible, and that the patients, especially in the case of children, can carry out their lives as close to their habitual one as possible (Cardenas \& Lopez, 2005-2006; Lopez \& Fernandez, 2006).

Research in the last few years has been orientated towards the search for solutions that could mitigate the effects of said hospitalization; in 1986, and according to this line of thinking, the European Parliament through the Resolution of the May 13 made "The European Letter for the Rights of Hospitalized Children” public, the following sections should be noted:

- The right of children to have access to furnished and equipped spaces which comply with their needs in terms of care, education and games as well as with the normal safety regulations.

- The right to schooling during their stay at the hospital and to benefit from the teachings of professionals as well as having access to didactic materials which the education authorities may put at their disposal, especially in the case of a prolonged hospitalization, on the condition that the aforementioned activity does not cause any harm to their well-being and/or stand in the way of the treatment being followed.

- The right to have at their disposal, during their hospitalization, toys, books and audiovisual aids adequate to their age.

- The right to receive schooling in the case of partial hospitalization or of convalescence in their home.

In recent years, education professionals have been gradually introduced into the clinics and hospitals of various countries, including Spain, in an attempt to cover the psychopedagogical needs of the hospitalized children as well as give quality attention to the families, that is to say, education 
es decir, educar y formar dentro de la situación particular de la enfermedad (Fernández, 2000; Grau Rubio y Ortiz González, 2001). Aunque en un principio los servicios pedagógicos fueron impulsados por los hospitales, en los últimos años, los ministerios de educación, han tomado las medidas oportunas desplazando a profesores con el fin de minimizar los riesgos de la hospitalización (Colom, 1997).

Como consecuencia de ello, la educación formal del usuario no se descuida. La Pedagogía Hospitalaria (Cárdenas y López, 20052006) debe ir más allá de la acción educativa formal (instrucción académica) y no debe estar centrada solo en la atención a las niñas y niños hospitalizados, sino que debe atender a las necesidades de toda la población del ámbito hospitalario. Este hecho intenta responder a un fenómeno objetivo de la realidad de nuestro tiempo, un intento de continuar con el proceso educativo de aquellas personas que están enfermas o convalecientes, de los familiares del mismo y de todas aquellas personas que intervienen en la vida del paciente.

En los inicios el foco de atención se centró en las aulas hospitalarias ${ }^{1}$ y la intervención en este campo se centraba únicamente en paliar déficits escolares de los niños y niñas que ingresaban en los centros hospitalarios. Hoy en día, abarca un mayor campo siendo objeto de su intervención cualquier sector de la población relacionado con el ámbito sanitario: pacientes de todas las edades, familiares, personal sanitario y población en general. Se debe propiciar, por tanto, la participación de todas las personas que interaccionan con el paciente, fundamentalmente, la familia.

Siguiendo con este razonamiento y teniendo en cuenta los derechos antes mencionados, tampoco debieran descuidarse las actuaciones educativas relativas a la animación hospitalaria. La animación hospitalaria está diseñada para la población que perma- and training within the particular situation of the illness (Fernandez, 2000; Grau Rubio \& Ortiz Gonzalez, 2001). Although these pedagogical services were initially promoted by the hospitals, in recent years it has been the ministries of education that have undertaken the necessary measures by sending in teachers in order to minimize the risks of the hospitalization (Colom, 1997).

As a result, the formal education of the user has not been ignored. The Hospital Teaching (Cardenas \& Lopez, 2005-2006) should go beyond the formal educational activities (academic instruction) and should not only concentrate on hospitalized children, but should also attend the needs of the complete hospitalized population. This fact is an attempted response to an objective phenomenon of our times, an attempt to continue with the educational process of hospitalized or convalescent patients as well as their relatives and all those people who may intervene in the life of a patient.

At the beginning, attention was focused on the hospital classrooms ${ }^{1}$ and the intervention in this field concentrated only on mitigating the harm caused by the lack of schooling of hospitalized children. Today, a much wider field is covered, concentrating on any sector of the population related with the public health sphere: patients of all ages, public health personnel and the population in general. The participation must be brought about, therefore, to encompass all the persons who interact with the patient, meaning, basically, their families.

Following this reasoning, and keeping the aforementioned rights in mind, the educational acts related to hospital animation should not be neglected. Hospital animation is designed for the population that has been admitted in the hospitals and has, consequently, a lot of free time. The benefici- 
nece ingresada en centros hospitalarios y dispone por ende, de mucho tiempo libre. Los efectos beneficiosos que de ella se derivan inciden no solo en el paciente pediátrico, sino también en los familiares del mismo. La atención a las familias de los pacientes debe ser elemento prioritario de la Pedagogía hospitalaria ya que la hospitalización infantil conlleva una serie de repercusiones negativas sobre la familia que se agravan si se acompaña de un diagnóstico de enfermedad crónica. Lozasoáin (2003) establece las consecuencias más comunes que tiene la hospitalización en la familia: impacto psicológico (ansiedad, estrés...); impacto físico (alteraciones del sueño, del apetito...); impacto ocupacional (bajas laborales, importantes gastos económicos...) e, impacto social (ruptura de relaciones sociales, sentimiento de que se les evita...). Por ello, la incorporación del educador social en los centros sanitarios complementaría los equipos interdisciplinarios que requiere la hospitalización, mediante la realización de una serie de actividades altamente gratificantes para el paciente y representando la conexión con lo cotidiano y el exterior. A falta de la puesta en marcha de equipos multidisciplinares en los centros sanitarios, el voluntariado se encarga de desempeñar esta labor.

El estudio que aquí describimos, supone la presentación de uno de los apartados de un proyecto de investigación, que sobre animación hospitalaria en el Hospital Materno-Infantil de la capital del Principado de Asturias, financió la Universidad de Oviedo (UNOV-o7MB-202).

El proyecto pretende ofrecer, tomando como referencia los estudios de Pedagogía, Educación Social y Enfermería, una visión conjunta de la animación hospitalaria, que incida directamente en un movimiento de gran predicamento a nivel internacional, como es el de la humanización de los hospitales. Por ello, nuestras actuaciones se vertebran en la fase de diagnóstico, en torno a dos ejes fundamentales: ary effects derived from the animation has a bearing not only on the patients but also on their relatives. The priority of hospital Pedagogy must give attention to the patients' families as child and infant hospitalization can involve a series of negative repercussions on the family that can worsen in the case of the diagnosis of a chronic illness. Lozasoain (2003) establishes the most common consequences of hospitalization on the family: psychological impact (anxiety, stress...); physical impact (sleep and eating disorders...) occupational impact (labour absenteeism, high economic expenses...) and, social impact (breaking off of social relations, feeling of being avoided...). Because of this, the incorporation of a social educator in health centres would compliment the interdisciplinary teams required by the hospitalization, by carrying out a series of activities which are highly gratifying for the patient and represent the connection with the everyday and exterior world. As interdisciplinary teams have not yet been established in the health centres, volunteers carry out these tasks.

The study here described, supposes the presentation of one of the sections of a research project financed by the University of Oviedo on hospital animation in the Materno-Infantil Hospital of the capital of the Principality of Asturias (UNOV-O7-MB202).

The intention of the project is to offer, taking as reference the Studies of Pedagogy, Social Education and Nursing, a joint vision of hospital animation, which has a direct bearing on a movement of great international prestige which is the humanization of hospitals. Because of this, our acts turn to the diagnostic phase, based around two, fundamental, axes:

[ 228 ] - María TeResa Bermúdez Rey y Susana Torío López

SIPS - REVISTA INTERUNIVERSITARIA DE PEDAGOGIA SOCIAL [1139-1723 (2012) 20, 223-242] • TERCERA EPOCA 
- En primer lugar se recogen las experiencias de los distintos actores implicados en los proyectos de animación hospitalaria: el voluntariado, el personal sanitario, los usuarios directos y los usuarios indirectos (las familias).

- En segundo lugar, se pone de manifiesto la presencia, o ausencia, de distintos mediadores ambientales simbólicos, de tipo estructural, decorativo y funcional, relacionados con la calidad de vida del paciente pediátrico en el hospital.

Con posterioridad y a la luz de los datos obtenidos, en la fase de intervención, se establecen pautas de actuación, con el fin de diseñar propuestas de mejora en los diferentes ámbitos estudiados.

En este artículo se pretende poner de manifiesto la percepción que los padres y madres de los pacientes pediátricos de dicho hospital tienen, sobre la animación llevada a cabo por distintas asociaciones de voluntarios, así como sobre otros aspectos afines a la misma. Hace referencia, por tanto, al primer apartado de la investigación, si bien centrándonos en las opiniones que los padres y las madres del paciente pediátrico tienen, sobre distintos aspectos de la animación realizada por voluntarios en el Hospital Materno-Infantil.

Aunque los principales protagonistas y beneficiarios de sus actuaciones son los pacientes pediátricos, nos interesa centrarnos en la percepción que las familias tienen sobre la animación hospitalaria. Para ello resulta relevante conocer la valoración que hacen de las actuaciones de las asociaciones implicadas, qué percepción tienen sobre sus condiciones de trabajo, si consideran suficientes los espacios y los materiales utilizados así como la formación de los voluntarios, cómo valoran los efectos que la animación tienen sobre sus hijos e hijas y sobre ellos mismos, si consideran o no necesaria la continuidad de la animación en el hospital, etc.
- In the first place, the experiences of the different agents implicated in the hospital animation projects: the volunteers, the medical staff, the direct users or clients and the indirect users or clients (the families).

- In second place, the presence or absence of different structural, decorative and functional environmental mediators related to the quality of life of the paediatric patient in the hospital should be stipulated.

Next, and in relation to the data obtained, during the intervention phase, acting guidelines are established with the aim of designing improvement proposals in the different fields studied.

This article intends to manifest the patients' parents' perception regarding the animation carried out by the different volunteer organizations, as well as other aspects related to the same. It refers, then, to the first section of the research, concentrating on the opinions the paediatric patients' parents have of the different aspects of the animation carried out by the volunteers in the Materno-Infantil Hospital.

Although the main agents and beneficiaries of their acts are the paediatric patients, we prefer to concentrate on the perception the families have regarding the hospital animation. To do so, it would be relevant to know their assessment of the performance of the associations involved, what their perception of the working conditions are, if they consider that the materials and spaces used are satisfactory as well as their opinion regarding the volunteers' training. In addition, their consideration regarding the effects of the animation on their children and on themselves, and whether the continuation of the hospital animation is considered worthwhile should also be noted.

LA PERCEPCIÓN DE LAS FAMILIAS ANTE LA ANIMACIÓN HOSPITALARIA... [ 229 ] SIPS - REVISTA INTERUNIVERSITARIA DE PEDAGOGIA SOCIAL [1139-1723 (2012) 20, 223-242] • TERCERA EPOCA 
La investigación pretende conocer en último término:

- El grado de aceptación por parte de las familias del paciente pediátrico, de las actividades de animación hospitalaria realizadas por dichas asociaciones; y, en consecuencia,

- Proponer que la animación hospitalaria posea un carácter de continuidad y profesionalización, en aras del beneficio que se presume posee, sobre el paciente pediátrico y sobre sus acompañantes.

Se parte por tanto de la siguiente hipótesis:

- Los padres y las madres avalan la animación realizada con los pacientes pediátricos en el hospital por los resultados beneficiosos que reporta.

\section{Metodología de la investigación}

En el Hospital Materno-Infantil de Oviedo, la edad del paciente pediátrico se encuentra comprendida entre los o y los 14 años de vida y se subdivide en tres periodos: de o a 3 años (lactantes), de 3 a 6 años (preescolares), de 6 a 14 años (escolares). De acuerdo con estas edades, los niños y niñas del Hospital Central de Asturias son atendidos en las diferentes Unidades adscritas al Servicio de Pediatría.

Para todo el área pediátrica existe un Aula Escolar, dirigida por dos maestras, que procuran que los niños ingresados no pierdan la conexión con su formación escolar, a la vez que organizan actos lúdicos para que su estancia en el hospital sea lo más agradable posible. Cuentan con una emisora de radio interna, biblioteca infantil, aula escolar, un canal privado de TV con vídeos infantiles y juveniles (canal 7), ludoteca, etc.

Estas actividades se ven apoyadas por el alumnado en prácticas de Ciclos Formativos de Educación Infantil, de la Facultad de Pedagogía, de la Escuela de Magisterio y profesorado en turno de tarde perteneciente a la
Finally, the research attempts to understand:

- The degree of acceptance of the activities of hospital animation carried out by the aforementioned associations on the part of the paediatric patients' families, and, in consequence,

- Propose that the hospital animation have continuity and become professionalized due to the benefits that it presumably has on the patients and their companions.

It starts on the basis of the following hypothesis:

- The parents endorse the animation carried out with the paediatric patients due to the benefits it provides.

\section{Research Method}

In the Materno-Infantil Hospital of Oviedo, the age of the paediatric patient ranges from o to 14 years old and is subdivided into three periods: from o to 3 year olds (unweaned), from 3 to 6 year olds (preschool) and from 6 to 14 year olds (school children). According to these ages, the children of the Central Hospital of Asturias are treated in the different Units attached to the Paediatric Services.

There is only one Classroom, run by two teachers, for the whole paediatric area. These teachers try to maintain the patients' connection with school while organizing recreational activities so that the stay at the hospital be the most pleasant possible. They have a private TV channel at their disposal with children's and adolescent programming (Channel 7) as well as a toy library.

These activities are reinforced with personnel comprised of the students in training obtaining their Associate's Degree in Childhood Education at the School of Pedagogy of the Teacher Training College and

[ 230 ] - María Teresa Bermúdez Rey y Susana Torío López

SIPS - REVISTA INTERUNIVERSITARIA DE PEDAGOGIA SOCIAL [1139-1723 (2012) 20, 223-242] • TERCERA EPOCA 
Concejalía de Servicios Sociales del Ayuntamiento de Oviedo, con un programa de animación a la lectura.

El centro cuenta con otros programas tales como el de Rehabilitación Pedagógica (P.R.P.) en la Unidad Pedagógica del Centro de Rehabilitación cuya finalidad es la habilitación del niño, joven o adulto con hospitalizaciones frecuentes o de larga duración que presentan dificultades de aprendizaje; el Programa de Animación Infantil (P.A.I.) en la Unidad Escolar del Centro Materno-Infantil, y el Programa de Atención Domiciliaria (P.A.D.), en la Unidad Itinerante, con sede en el Centro Materno-Infantil. (Bermúdez y Torío, 2007).

Son cuatro las asociaciones encargadas de realizar animación con niños en el Hospital Materno-Infantil de Oviedo: Cruz Roja, GALBÁN, SED (Solidaridad, Educación y Desarrollo) y Fundación "La Caixa".

Para la recogida de datos se elaboró un cuestionario de 25 ítems destinado a los padres de los enfermos pediátricos. Las variables de estudio se agrupan en torno a cuatro amplias dimensiones:

a) Datos sociodemográficos: sexo y edad de la persona que responde al cuestionario.

b) Datos referidos al paciente pediátrico: edad, tiempo de hospitalización, uso del tiempo libre, preferencias de juego en el hospital, procedencia de los juegos (asociación, el hospital, los padres, otros), lugares de juego (habitaciones, sala de animación, aula hospitalaria, otros).

c) Relaciones de los familiares con el voluntariado y la animación: efectos que su labor tiene sobre el niño y los acompañantes, etc.

d) Preferencias con respecto al hospital y la habitación del paciente.

Concretamente, los objetivos que nos hemos planteado desarrollar en estas páginas, tienen que ver con los tres primeros apartados. the professors working the evening classes belonging to the Department of Social Services of the Oviedo City Hall, which offers a reading encouragement programme.

The centre has other programmes such as the Pedagogical Rehabilitation Programme (P.R.P.) in the Pedagogical Unit of the Rehabilitation Center the goal of which is the integration of a frequently hospitalized or long-term hospitalization of a child, youth or adult who presents learning difficulties; the Programme of Childhood Animation at the Education Unit of the Materno-Infantil Center and the Home Care Programme of the Mobile Unit, based in the Materno-Infantil Center (Bermudez \& Torio, 2007).

There are four associations responsible for children's animation in the Materno-Infantil Hospital of Oviedo: Cruz Roja, GALBÁN, SED (Solidarity, Education and Development) and the "La Caixa" Foundation.

A questionnaire of 25 items was drawn up in order to gather data from the parents of the paediatric patients. The variables of the study were grouped around four wide dimensions:

a) Sociodemographic data: sex and age of the person doing the questionnaire.

b) Data referring to the paediatric patient: age, length of hospitalization, use of free time, game preferences while in the hospital, origin of the games (association, hospital, parents, others) places where the games are played (hospital room, common room, hospital classroom, others).

c) Relation of the family with the volunteers and the animation carried out by them: effects of said activities upon the child and companions, etc.

d) Preferences regarding the hospital and the patients' room.

Concretely, the objectives set to be developed in this study have to do with the first three sections. 
Respecto a la aplicación de los cuestionarios, que se realizó a lo largo de los meses de abril y mayo de 2007, y previa tramitación de los permisos pertinentes, es necesario admitir que ha sido una labor no exenta de dificultades, debidas sobre todo al propiciar el encuentro con las familias. No obstante, destacamos el interés mostrado hacia nuestra labor, tanto por la trabajadora social del Hospital Central de Oviedo, como por los coordinadores de cada una de las asociaciones.

Los análisis estadísticos se han realizado con el programa R ( R Development Core Team, 2007). Dado el carácter descriptivo, exploratorio y explicativo del mismo, se han utilizado técnicas - desde el procesamiento de la información a nivel descriptivo (media, mediana, valor máximo y mínimo, desviación típica) hasta otras inferenciales de carácter paramétrico y no paramétrico (análisis de contingencia principalmente)- que han ayudado a resaltar las relaciones entre las variables de la realidad estudiada.

\section{Análisis e interpretación de los datos}

Los cuestionarios declarados útiles fueron 54, siendo cumplimentados por el padre, la madre, por ambos miembros de la pareja o por otros familiares que acompañaban asiduamente al paciente. Por lo que respecta a la persona que ha cumplimentado el cuestionario, el $81,5 \%$ de los encuestados son mujeres y el $16,7 \%$ son varones. En cuanto a la edad, el $1,9 \%$ tienen una edad menor de 20 años; el $24,1 \%$ oscilan entre 20 y 30 años; el 40,7 \% tienen entre 30 y 40 años, y el 33,3\% son mayores de 40 años. Por tanto, en su mayor parte los cuestionarios son cumplimentados por la madre y su edad es superior a los 30 años.

Algunos datos relacionados con el enfermo hospitalizado son los siguientes: respecto a la edad, la mayoría de los niños $(53,7$ $\%)$ tienen una edad entre 5 y 10 años; el $25,9 \%$ son mayores de 10 años, y el 20,4\% se sitúan entre los o y 4 años.
Regarding the application and previous processing of the permits needed for the interviews, carried out during the months of April and May of 2007, it should be mentioned that it has been a difficult undertaking, due mainly to the problems encountered when organizing meetings with the families. Nonetheless, the interest in the study shown by social worker of the Central Hospital of Oviedo and by the coordinators of each of the associations has been noteworthy.

The statistic analyses have been carried out with the R programme (R Development Core Team, 2007). Given its descriptive, exploratory and explicative nature, certain techniques have been used - from the processing of descriptive information (average, median, maximum and minimum values, standard deviation) to other parametric and non-parametric differentials (principally contingency analysis) - which have helped to highlight the relations between the variables of the studied reality.

\section{Data analysis and interpretation}

There were 54 questionnaires which were considered useful, as they were filled out by the father or mother, by both parents or by other relatives who regularly accompanied the patient. Regarding the persons who filled out the questionnaire; $81.5 \%$ were women and $16.7 \%$ were males. Regarding their ages, $1.9 \%$ were under 20 years of age; $24.1 \%$ were between 20 and 30 years old, and $33 \%$ were over 40 . Hence, the majority of the questionnaires were filled out by mothers who were over 30 years old.

Some of the data related to the hospitalized are the following: regarding their age, the majority of the children $(53.7 \%)$ are between 5 and 10 years old; $25 \%$ are over 10 years old and $20.4 \%$ are between $\mathrm{o}$ and 4 years old. 
En cuanto al tiempo de hospitalización, se consideró esta larga, si era de un mes; muy larga si se extendía varios meses; o corta o muy corta, si comprendía una semana o menos días. La hospitalización corta supone el $74,1 \%$; la hospitalización larga, el 22,2\%, y la muy larga, el 3,7\%.

El tiempo de hospitalización guarda una relación estadísticamente significativa según la edad de las personas entrevistadas $\left(\chi^{2}=12.63 ; p<0.05\right)$. En el caso de las familias con una edad de menos de 20 años la persona entrevistada, el 100\% de los hijos e hijas tienen una hospitalización larga; las familias entre 20 y 30 años, la hospitalización de su hijo o hija es corta en un 69\%; y, en las familias de más de 30 años, la hospitalización de su hijo o hija es entre una semana o menos y un mes.

La mayoría de los niños de este estudio afronta hospitalizaciones cortas, hecho que coincide con la tendencia actual de la realidad hospitalaria y hace suponer que al menos parte de la posterior recuperación se realizará en los domicilios, por ello es previsible que deba contemplarse una animación que tenga en cuenta otros ámbitos, además del hospitalario. A este respecto López y Fernández (2006), destacan que en los últimos años ha aumentado la hospitalización de niños en los centros hospitalarios, así como la visita a unidades ambulatorias y el diagnóstico y el tratamiento precoz, lográndose el paso de una hospitalización prolongada a la breve. Ello repercute en una modificación en el modo de intervención educativa a través de programas específicos.

Por lo que respecta al uso del tiempo libre, la mitad de los niños según la percepción de sus padres, se aburre en el hospital, mientras que otro $50 \%$ de los enfermos no lo hace.

Interesa resaltar la falta de espacios específicos en el hospital para llevar a cabo la animación, así por lo que respecta al lugar de juego el 54,7\% de los pacientes juega en la habitación; el 52,8\% lo hace además en el
The length of hospitalization was considered long if it lasted a month, very long if it lasted various months, or short or very short if it lasted a week or less. Short hospitalization comprised $74.1 \%$; long hospitalization $22.2 \%$, and very long hospitalization $3.7 \%$.

The duration of the hospitalization maintains a significantly statistical relation according to the age of the persons interviewed $\left(\chi^{2}=12.63 ; p<0.05\right)$. In the case of families in which the person interviewed was under $20,100 \%$ of the children underwent a long hospitalization; $69 \%$ of families whose members were between 20 and 30 years of age had their children hospitalized for a short period; and families whose members were over 30 had a hospitalization period ranging from one week or less and one month.

The majority of the children in this study faced short hospitalizations, a fact that coincides with the current tendency of hospital reality and presupposes that at least part of the latter convalescence will take place at home. Due to this, it is foreseeable that some animation must take other surroundings, not only hospitals, into consideration. In this regard, Lopez and Fernandez (2006), emphasize that, in recent years, there has been an increase in child hospitalization, and in visits to outpatient units as well as in early diagnoses and treatment thus achieving a shift from long hospitalizations to shorter ones. This has a direct repercussion on the form of educational intervention through specific programmes.

According to the parents regarding the use of free time, half of the children get bored in the hospital while the other $50 \%$ do not. It is important to note the lack of specific areas in the hospital to carry out the animation, thus, $54.7 \%$ of the patients play in their hospital rooms, $52.8 \%$ do so in the hospital classroom and $13.2 \%$ use 
aula hospitalaria; el 13,2\% utiliza las salas del hospital, y se asegura que en otros lugares no juega nadie.

Pero aun teniendo en cuenta la afirmación anterior, se sabe que la mitad de los enfermos de este estudio se aburre en el hospital y que su tiempo libre es ocupado en utilizar medios audiovisuales o en jugar, no realizándose otras actividades. Con relación al uso que el paciente hace del tiempo libre, este es empleado por un $72,2 \%$ en utilizar medios audiovisuales; también en jugar, 75,9\% o realizar otras actividades, 5,6\%.

Los niños de este estudio juegan con sus padres y madres (en un 74,1\%), con los voluntarios (37\%), y con los hermanos $(25,9 \%)$, existiendo un porcentaje muy bajo de enfermos, 3,7\%, que no juegan con nadie. A este respecto, algunos autores como Benavides, González, Tévar y Barahona (1997) han puesto de manifiesto como el nivel de satisfacción que los padres y madres muestran con el hospital viene determinado por las buenas relaciones con el personal sanitario, a través del cuidado médico, la información recibida o la accesibilidad, y por factores de tipo organizativo como la alimentación, horas de visita... y la oferta de actividades recreativas. Para las familias entretener a los niños y niñas no es tarea fácil estando como están, preocupados por las enfermedades de sus hijos y por su posible evolución, cansados por las incomodidades que sufren en el hospital y agobiados por los problemas y complicaciones familiares y laborales, que surgen como consecuencia de dicha hospitalización.

En cuanto a la procedencia de los juegos, los padres creen en un $62,3 \%$, que los juegos los proporciona el hospital; en un $28,3 \%$ aseguran que los proporcionan los voluntarios; mientras que en $49,1 \%$, se admiten que son los familiares los que los llevan. Palomo (1995) ya advertía que el aburrimiento prolongado del niño hace que se vaya entristeciendo y acabe adoptando una actitud pasiva e indiferente ante lo que antes le entretenía. El juego en el the common areas and none play in other spaces.

When considering the previous issue, it is understood that half of the patients in this study are bored while in the hospital and that their free time is taken up by the use of audiovisuals or in playing games, not carrying out any other activities. In relation to how the patients employ their free time, $72 \%$ use audiovisual equipment, $75.9 \%$ play games and $5.6 \%$ use it for other activities.

$74.1 \%$ of the children in this study play with their parents, $37 \%$ do so with the volunteers, $25.9 \%$ with their siblings and a very low percentage, $3.7 \%$ do not play with anyone. In regard to this, some authors, such as Benavides, Gonzalez, Tevar and Barahona (1997) have demonstrated how the parents' level of satisfaction with the hospital is determined by the relations with the hospital personnel, by the medical care, by the access to, or information received, and by organizational factors such as meals, visiting times... and the recreational activities available. It is not easy for the families to keep their children entertained as they are worried about their child's condition and the possible evolution of the illness, or tired due to the inconvenience of spending time in the hospital or simply overwhelmed $b$ the problems and familiar complications that have arisen as a consequence of said hospitalization.

In terms of the origin of the games, parents believe that $62.3 \%$ of the games are provided by the hospital, $28.3 \%$ claim that they are provided by the volunteers and 49.1\% admit that the games are provided by the families themselves. Palomo (1995) had already alerted that prolonged boredom of the hospitalized child could result in increased sadness and a passive and indifferent attitude towards what was once entertaining for them. Play, in the hospital provides the patient with a sense of well- 
hospital le proporciona al paciente, bienestar y confianza, cumpliendo a la vez con las funciones recreativa, educativa y terapéutica.

Igualmente los padres y madres de este estudio muestran desconocimiento acerca de la procedencia de los juegos utilizados por los niños ingresados, asegurando que los aporta el hospital, que son propios, o en último término que son facilitados por el voluntariado, cuando se sabe que son las asociaciones las que los proporcionan (según las mismas en un $90,5 \%$ el suministro del material corre a su cargo) y disponen además para guardarlos, de una sala de dimensiones reducidas que gestionan de común acuerdo.

En todo caso, en los hospitales no existe ni abundancia ni variedad de recursos para entretener a los niños y, por tanto, no es de extrañar que sea frecuente ver en las habitaciones de los pacientes a padres y a niños desalentados, o que los niños sostengan lo aburridos que son los días en el hospital, lo que indica hasta que punto su bienestar psicológico está determinado por cómo se entretienen, juegan o pasan el tiempo.

Se ha encontrado relaciones estadísticamente significativas entre la edad de la persona que responde al cuestionario y la realización o no de otras actividades por las tardes $\left(\chi^{2}=19.35 ; p=0.000\right)$. Los entrevistados menores de 20 años han respondido que sí en un 100\%; sin embargo, los entrevistados entre 20 y 30, así como los mayores de 40 años han contestado en un $100 \%$ que no en esta variable "por la tarde otras actividades". Los entrevistados entre 30 y 40 han respondido en un $90 \%$ que no.

En relación con este resultado se ha encontrado otra relación estadísticamente significativa entre la edad del entrevistado y la variable "juega con nadie" $\left(\chi^{2}=27.24\right.$; $\mathrm{p}=0.000)$. Se reproducen los mismos porcentajes en las mismas categorías: menores de 20 años han contestado en un cien por cien sí en esta variable, concentrándose en las otras tres categorías de "no". being and confidence, fulfilling recreational, educational and therapeutic needs.

Although the parents in this study do not know the origin of the games used by their hospitalized children, or assure that they are provided by the hospital, that they are their own, or lastly, that they are provided by the volunteers, it is known that they are really provided by the associations (according to which, 90.5\% of the material is provided by them) and that they have a small area for their storage which is $\mathrm{co}^{-}$ managed.

In any case, as a result of there being neither abundance nor variety of resources for entertaining the children, it is not surprising to frequently find discouraged parents and children in the hospital rooms or that the children maintain that the days in the hospital are boring which indicates to what point there psychological well being is determined by how they are entertained, play or spend their time.

There is a statistically significant relation between the age of the person responding to the questionnaire and the carrying out, or not, of other activities during the afternoons $\left(\chi^{2}=19.35 ; p=0.000\right)$. Those interviewed under 20 years of age have had an affirmative response of $100 \%$; however, the interviewees between 20 and 30 years of age, as well as those over 40 have had a negative response of 100\% in the variable "other activities in the afternoon". The interviewees between 30 and 40 years of age have had a negative response of $90 \%$.

Another statistical relation has been discovered related with this result between the age of those interviewed and the "plays with no-one" variable $\left(\chi^{2}=27.24 ; p=0.000\right)$. The same percentages are to be found in the same categories, interviewees under 20 years of age have responded affirmatively $100 \%$ to this variable, concentrating negatively in the other three categories. 
Por lo que respecta a los hermanos del enfermo, la experiencia de los voluntarios dedicados a la animación en el hospital MaternoInfantil, asegura que las actividades realizadas contemplando la conjunción paciente-hermano, consiguen una participación más activa de la niña o niño ingresado, para el voluntariado el hermano se convierte en un valioso soporte para el educador, pero la decisión de incluirlo en las actividades dependerá del estado anímico del paciente, del tiempo que lleva ingresado y de la edad (Bermúdez, 2007a); esta recomendación no coincide con la percepción del personal sanitario, ya que más de la mitad de los encuestados, considera que no es necesario realizar animación con los mismos, aunque a veces pueda ser conveniente.

Los padres señalan que la mayoría de las niñas y niños juega en la habitación (percepción que coincide con la del voluntariado) o en el aula hospitalaria, muy pocos lo hacen en la sala de animación y ninguno, en otros lugares. Como es sabido, la necesidad de llevar a cabo la animación hospitalaria queda muchas veces "parapateda", tras la puesta en marcha y funcionamiento de las llamadas aulas hospitalarias, aun así las aulas tienen un problema, y es que funcionan solamente durante el curso escolar y de acuerdo por tanto, con un calendario lectivo. A esto hay que añadir la precariedad en la que se ven inmersas las asociaciones, ya que se movilizan por razones altruistas y no siempre disponen de un montante económico que facilite la continuidad de su labor, aun a sabiendas de los grandes beneficios que le reportan al paciente pediátrico.

La instalación de las ciber@ulas hospitalarias ha tenido una gran aceptación por parte del enfermo, su distribución en cuatro espacios hace que goce de una gran concurrencia a lo largo del día. Pero en general puede afirmarse que no existen en los centros sanitarios grandes salas de animación, ni ludotecas que hagan atractiva la relación con igua-
Regarding the patients'siblings, the experience of the hospital animation volunteers in the Materno-Infantil Hospital, assures that the activities carried out that have contemplated the combination of patient-sibling have achieved a greater level of active participation on the part of the hospitalized child. While the sibling becomes a valuable support for the educator the decision of whether or not to include them in the activities depends on the patients' state of mind, the length of the hospitalization, and their age (Bermudez, 2007a). This recommendation does not $\mathrm{CO}^{-}$ incide with that of the medical staff, as more than have of those surveyed consider that it is not necessary to carry out the animation with the siblings, although it may sometimes be convenient.

The parents have indicated that most of the children play either in their rooms (the volunteers agree with this view) or in the hospital classroom, very few do so in the animation area and none, in other areas. As is already known, the hospital animation is often "brushed under the carpet", once the hospital classrooms have been set up. However, there is a problem involved with these classrooms, and that is that they are only in use during the school year and as a result, adhere to the regular school calendar. A second problem is the precarious situation which many of these associations find themselves in as they are motivated by altruistic reasons and do not always have economic funding which may facilitate the continuity of work they carry out despite the great benefits this may have for the paediatric patient.

The installation of the hospital cyberclassrooms has had a great acceptation on the part of the hospitalized patients, its four part distribution favours attendance throughout the day. It may be asserted, however, that there are no animation areas nor toy libraries which make peer to peer

[ 236 ] - María TeResa Bermúdez Rey y Susana Torío López

SIPS - REVISTA INTERUNIVERSITARIA DE PEDAGOGIA SOCIAL [1139-1723 (2012) 20, 223-242] • TERCERA EPOCA 
les, ni se recurre a la explotación de otros espacios ya existentes en el hospital.

A pesar de todo, y según la percepción de los padres y madres, el efecto de las actuaciones del voluntariado sobre el estado anímico de los niños se considera positivo o muy positivo, dicha aseveración coincide radicalmente con la de todo el personal sanitario quién asegura que la animación hospitalaria es necesaria y que incluso, se observa una mejoría en los niños que la reciben (96,6\%).

En cuanto a las relaciones que los familiares mantienen con los voluntarios y los efectos que su labor tiene sobre la niña o el niño y los acompañantes se comprueba que:

- La influencia que la labor del voluntariado tiene sobre la hospitalización, se considera positiva $(52,8 \%)$ o muy positiva $(45,3 \%)$, y de acuerdo con lo anterior, la dedicación temporal del voluntariado contabilizada en horas, se considera a juicio de los padres y madres, escasa (el 98\% de los encuestados destaca la necesidad de más horas). Concretamente, el cien por cien de las madres han considerado la necesidad de más horas de dedicación por parte de los y las voluntarias $\left(\chi^{2}=15.05 ; p<0.05\right)$.

- La relación mantenida entre las familias y el voluntariado se considera, en general, buena $(54,7 \%)$ o excelente $(26,4 \%)$.

- Ya que la enfermedad afecta al paciente pediátrico y a su familia, se observa que los efectos que el trabajo del voluntariado tiene sobre los padres, le permiten a estos relajarse o descansar (94,3\%) e igualmente se pone de manifiesto que la animación se realiza también con los hermanos $(76,6 \%)$.

- Por último, se constata cómo los padres y las madres consideran necesaria la animación hospitalaria con los pacientes pediátricos (100\% de los encuestados).

Los padres y madres encuestados creen que los voluntarios debieran ampliar su presencia en el hospital, afirmación que no pa- relations attractive nor are any other existent spaces put to this use. Despite this, and according to the parents, the effect of the volunteers' actions on the state of the patients is considered positive or very positive. This assertion coincides radically and to a great degree with that of the hospital staffs who assure that the hospital animation is necessary and what is more, results in an observable improvement in those children who receive it $(96,6 \%)$.

Regarding the relations that the relatives have with the volunteers and the effect of their work on the children and their accompanying family members it may be observed that:

- The influence the volunteers' work on the hospitalization is considered positive $(52.8 \%)$ or very positive $(45.3 \%)$, and according to this, the time invested, counted in hours, is considered by the parents to be scarce $(98 \%$ of those in terviewed emphasized the need for more hours). Specifically, 100\% of the mothers consider that more time should be invested on the part of the volunteers $\left(\chi^{2}=15.05 ; \mathrm{p}<0.05\right)$.

- The relation between the volunteers and the family is considered, in general, to be good $(54,7 \%)$ or excellent $(26,4 \%)$. - As the illness affects the paediatric patient and their families, it may be observed that the effect of the volunteers' work on the parents permits them to relax or rest $(94.3 \%)$ and it is noted that this animation is also performed on the siblings $(76.6 \%)$.

- Finally, it is noted that the parents consider hospital animation with paediatric patients necessary $(100 \%$ of those surveyed).

The parents consider that there should be a greater presence of volunteers in the hospital. This affirmation does not seem

LA PERCEPCIÓN DE LAS FAMILIAS ANTE LA ANIMACIÓN HOSPITALARIA... [ 237 ] SIPS - REVISTA INTERUNIVERSITARIA DE PEDAGOGIA SOCIAL [1139-1723 (2012) 20, 223-242] • TERCERA EPOCA 
rece gratuita si se añade además, que la actuación de los voluntarios les permite descansar, pudiendo ofrecer más tarde al paciente, acompañamientos de calidad. Esto concuerda con la información que proporciona el voluntariado, ya que en la mayoría de los casos desempeñan su labor una vez a la semana, y casi la mitad, invierte en ella una hora (Bermúdez 2007b; Bermúdez y Torío, 2007).

Por otra parte los voluntarios también señalan que para realizar bien su labor necesitarían más formación, más disponibilidad, más espacio y más tiempo para realizar actividades.

Lo anteriormente mencionado junto con la concluyente respuesta de las familias y del personal sanitario en cuanto a la necesidad de que los centros sanitarios oferten actividades de animación hospitalaria, parecen exigir la profesionalización de la animación, garantizando su permanencia en el tiempo. Se sabe que la animación realizada en contextos hospitalarios favorece la atención integral del paciente hospitalizado y es un instrumento fundamental para la participación directa y activa del enfermo en el hospital, al mismo tiempo que proporciona compañía y apoyo emocional (Bermúdez, 2009).

\section{Conclusiones}

La necesaria puesta en marcha de actuaciones de animación en el hospital, no ha supuesto hasta ahora un panorama demasiado alentador para el paciente pediátrico. Como ponemos de manifiesto en este estudio se sigue trabajando desde la ocasionalidad y no se tiene en cuenta a los profesionales encargados de desarrollar esta labor.

De acuerdo con la percepción de los padres y madres con respecto a la hospitalización de sus hijos e hijas en cuanto al tiempo libre y la ocupación del mismo a través de la animación hospitalaria realizada en el Hospital Materno- Infantil de Oviedo, po- gratuitous if it is also noted that the work of the volunteers allows them time to rest, thus providing them with the possibility of being able to later offer a better quality of company. This concurs with the information given by the volunteers as in the majority of the cases they carry out their work once a week and almost half of them do so in an hours' time (Bermudez 2007b; Bermúdez and Torio, 2007).

The volunteers, on their part, also point out that they would need more training, more availability, greater space, and more time in order to properly carry out their jobs.

What has been previously stated along with the conclusive response from the families and the hospital staff regarding the need for the health centres to offer hospital animation activities appears to indicate the need of professionalization of the animation, thus guaranteeing its continuity. It is known that the animation carried out in the context of a hospital favours the comprehensive attention of the hospitalized patient and is a fundamental instrument to achieve the active and direct participation of the patient in the hospital, while providing company for them as well as emotional support (Bermudez, 2009).

\section{Conclusions}

The need for the undertaking of hospital animation has not provided, up to this point, a very hopeful outlook for the paediatric patient. As is stated in this study, work continues on a temporary and unstable basis and the professionals who are in charge of carrying out these tasks are not considered.

According to the parents, in regard to their children's free time and the hospital animation activities with which this time is occupied, during their hospitalization in the Materno- Infantil Hospital of Oviedo, it may be concluded that they confirm the 
demos concluir que es importante y muy útil; los padres y madres encuestados ratifican la animación realizada en el hospital por los resultados beneficiosos que reporta tanto al paciente pediátrico como a los acompañantes. Sin embargo, precisan que dichas actuaciones deben contar con mayor atención, continuidad y ampliar sus espacios y tiempos.

Es acuciante respecto a la animación hospitalaria:

- La necesaria profesionalización, generalizando la contratación de educadores sociales en los centros hospitalarios con el fin de que la animación hospitalaria tenga una presencia continua en los hospitales, a la vez que este profesional se encargue de coordinar la labor del voluntariado, o mantenga una relación estrecha con una figura destinada a tal fin. Dicha conclusión ha sido constatada igualmente en otros trabajos (Ochoa Linacero, 2002: 51), se ve factible y útil la presencia de voluntarios en los hospitales, siempre y cuando estén coordinados y dirigidos por profesionales (médicos, enfermeras, psicólogos, pedagogos, trabajadores sociales, etc.) y sería deseable buscar formas de colaboración con los diferentes estamentos profesionales en los centros sanitarios con el fin de que no aparezcan posibles "solapamientos" en las funciones $y$, por tanto, conflictos.

- Necesidad de formar a profesionales dedicados a la formación del voluntariado, y en consecuencia invertir más recursos en dicha formación a través de cursos específicos, según necesidades asistenciales y temáticas específicas. De igual modo, la inexistencia de una evaluación formal y específica del trabajo de los voluntarios (ni por parte de las asociaciones ni de los centros sanitarios) así como documentos legales que regulen su presencia en los centros (constatado, igualmente, en otros estudios, Moix, 2001). beneficial results of said activities on the paediatric patient as well as on their companions. However, they have stipulated that these activities should be given more attention, continuity and greater space and time.

The following points regarding hospital animation are especially urgent:

- The need for professionalization, by generalizing the hiring of social educators in the health centres in order to obtain a continuous presence of hospital animation in the hospitals, while providing a professional who may direct the volunteers' work while maintaining a close relation with those people carrying out said tasks. This conclusion has also manifested itself in other studies (Ochoa Linacero, 2002: $51)$, and the presence of volunteers in the hospital is considered useful, when and if they are directed and coordinated by professionals (doctors, nurses, pedagogues, social workers, etc) and it would be desirable to establish different forms of collaboration among the different levels of professionals in the health centres with the objective of avoiding any possible "overlapping" of their duties and, as a result, any conflicts.

- The need to train professionals assigned to the training of the volunteers, and, as a consequence, a need for a greater investment of resources in said training through specific courses according to the welfare and specific thematic needs. In the same way, there is a lack of a formal and specific evaluation of the volunteers' work (neither by the associations nor the health centres) as well as legal documents which will regulate their presence in the centres (also specified in other studies, Moix, 2001). 
- Consideración del voluntariado como un servicio más del hospital, dotándolo de los recursos y espacios más adecuados.

- Generalización de la animación hospitalaria a todos los pacientes y no sólo a los enfermos de menor edad.

No olvidemos que a través de las actividades programadas desde la animación hospitalaria, se estará contribuyendo a mejorar la calidad de vida del paciente pediátrico mediante la realización de actividades lúdicas en su tiempo libre, contribuyendo de esta forma a integrarse en el hospital y reduciendo el estrés, la ansiedad y el aislamiento que genera la hospitalización (Bermúdez, 2006, 2007b)

Por último, debemos tener en cuenta que el grado de adaptación de los centros hospitalarios a las necesidades psicosociales del niño enfermo, puede ser considerado como un indicador de su calidad asistencial (Ullán y Belver, 2004). Sin duda, debido a cuestiones principalmente económicas, actualmente la Pedagogía Hospitalaria está dirigida especialmente al ámbito infantil (Cárdenas y López, 2005-2006) aunque la educación que ofrece esta rama de la pedagogía también debe estar a disposición de aquellos adultos que padecen una enfermedad por el simple motivo del derecho de todas las personas a la educación.

\section{Referencias bibliográficas/Referencces}

Asociación de Familias de niños con Cáncer del Principado de Asturias (GALBAN) (2010). Recuperado de: http://www.galban.org .

Benavides, G.; González, R.; Tévar, M. P. \& Barahona, A. (1997). Relation between satisfaction with health care and perception of the severity of illness in parents of children with cancer. Presentado en la $11^{\text {th }}$ Conference of the European Healh Psychology Society. Burdeos.

Bermúdez Rey, M. T. (2006). La animación Hospitalaria. En Ventosa, V. (Coord.), Perspectivas ac-
- Consideration of the volunteers as another service offered by the hospital, granting them the necessary resources and spaces.

- Generalization of hospital animation to all the patients and not only to minors who are ill.

It should not be forgotten that through the activities carried out by the hospital animation the paediatric patients' quality of life is being improved via the recreational activities carried out in their free time, thus contributing to the patients' integration in the hospital and reducing the stress, anxiety and isolation that may be generated by the hospitalization (Bermudez, 2006, 2007b).

Finally, it should be kept in mind that the degree of adaptation of hospitals to the psychosocial needs of the sick children may be considered as an indicator of their welfare quality (Ullán \& Belver, 2004). Without doubt, due mainly to economic questions, currently Hospital Pedagogy is mainly aimed at the field of childhood (Cardenas \& Lopez, 2005-2006) although the education offered by this branch of pedagogy should also be at the disposal of those adults who suffer from illness due to the simple right that everyone has to an education. tuales de la Animación Sociocultural. (pp. 331-342), Madrid: CCS.

Bermúdez Rey, M. T. (2007a). Os outros meninos hospitalizados: a óptica da animaçâo hospitalar. En J. Dantas, M. Vieites, y M. De Sousa (Coord.), Animaçâo, Artes y Terapias (pp.133-141). Ponte de Lima: Intervençâo-Associaçâo para a Promoçâo e Divulgaçâo Cultural.

Bermudez Rey, M. T (2007b). A Animaçâo hospitalar. En A. Nunes, A. y M. De Sousa (Coord.), Animaçao sociocultural. Novos desafíos. Chaves: Associaçâo Portuguesa de Animaçâo e Pedagogía (APAP). 
Bermudez Rey, M. T. (2009). A Animaçâo hospitalar no contexto da Terceira Idade. En J. Dantas Lima Y M. DE Sosa Lopes (Coord.), Animaçâo Sociocultural na Terceira Idade. Chaves: IntervençâoAssociaçâo para a Promoçâo e Divulgaçâo Cultural, pp 249-257.

Bermudez Rey, M.T. Y Torio Lopez, S. (2007). El voluntariado y la animación hospitalaria. En M. Cid, Y A. Peres (Coord.), Educación Social, Animación Sociocultural y Desarrollo Comunitario (pp. 5886o1). Universidad de Vigo Universidad de Tras os Montes e Alto Douro y Sociedad Iberoamericana de Pedagogía Social.

Cárdenas Rodríguez, R. y López Noguero, F. (20052006). Hacia la construcción de un modelo social de la Pedagogía Hospitalaria. Pedagogía Social. Revista Interuniversitaria, 12-13, pp. 59-70.

Colom, A.J. (1997). Teorías e Instituciones contemporáneas de la educación. Barcelona: Ariel Educación.

Cruz Roja Juventud (2007). Programa de Animación Hospitalaria. Oviedo: Cruz Roja Juventud Asturias.

FEPNC (Revista de la Federación Española de Padres de Niños con Cáncer) (2011). Recuperdo de: http://www.cancerinfantil.org.

Fernández Hawrylak, M. (2000). La Pedagogía hospitalaria y el pedagogo hospitalario. Tabanque, 15, pp. 139-150.

Fundación “La Caixa” (2009): ciber@ulas hospitalarias. Recuperado de: http://wwwfundacios.lacaixa.es).

González Jiménez, F.E.; Macías González, E. Y García Hernández, F. (2002). La Pedagogía hospitalaria: reconsideración desde la actividad educativa. Revista Complutense de Educación, 13 (1), pp.303365.

Grau Rubio, C. y Ortiz González, C. (2001). La pedagogía hospitalaria en el marco de una educación inclusiva. Málaga: Ediciones Aljibe, S.A.
Lizosoáin, O. (2003). Los retos de la atención educativa: del alumnado hospitalizado o convaleciente en el siglo XXI. En AA.VV., Memoria de las IX Jor nadas de Pedagogía Hospitalaria. Guadalajara: Federación Española de Niños Con Cáncer.

López Naranjo, I. y Fernández Castillo, A. (2006). Hospitalización infantil y atención psico-educativa en contextos excepcionales de aprendizaje. Revista de Educación, 341, pp 553-577.

Moix, J. (Coord.). (2001). Situación actual del voluntariado hospitalario en España. Associació pel Voluntariat a Europa. Barcelona: Edivurtual Book, S.A.

Ochoa Linacero, B. (2002). Reflexiones en torno al voluntariado hospitalario en Navarra. Pedagogía Social. Revista Interuniversitaria, 9, Segunda Época, pp. 41-52.

Palomo, M.P. (1995). El niño hospitalizado: características, evaluación y tratamiento. Madrid: Pirámide.

Quiles, M. y Pedroche, S. (2000). El papel de los padres en la preparación psicológica a la hospitalización infantil. En J. Ortigosa y F. Méndez (Eds.), Hospitalización infantil: Repercusiones psicológicas. Teoría y Práctica, (pp 155-174). Madrid: Biblioteca Nueva.

Serradas, M.; Ortiz, M.C. y De Manueles, J. (2002). Necesidad de asistencia educativa al niño hospitalizado. Enseñanza, 20, pp 243-258.

Sociedad Española de Cirugía Pediátrica (2005): Derechos del niño hospitalizado. Recuperado de: http://www.secp.org .

Solidaridad, Educación y Desarrollo (SED) (2006): SED. Recuperado de: http://www.sed-ongd.org.

Ullán, A.M. y Belver, M. (Dir) (2004). Los niños en los hospitales de Castilla y León: disposición y organización de espacios, tiempos y juegos en la hospitalización infantil en la SACYL. Recuperado de: http://www.ucm.es.

VV.AA (2007). R Development Core Team R: A language and environment for statistical computing. Viena. 
Notas

${ }^{1}$ Para más informació, véase González, Macías y García (2002). En este artículo se puede obtener una reflexión sobre cómo hacer que los alumnos del sistema educativo que por razones de enfermedad permanecen hospitalizados no solo no pierdan, en lo posible, su ritmo escolar sino que se vean asistidos eficazmente por la acción educativa. De igual modo, se adjunta una amplia bibliografía sobre la temática de Pedagogía Hospitalaria

\section{DIRECCIÓN DE LAS AUTORAS/}

\section{AUTHORS' ADDRESSES:}

Maㅡ Teresa Bermúdez Rey. EU Educación Social (EUPO). Universidad de Oviedo. C/Sacramento 12. $3^{\underline{0}}$ A. 33008 Oviedo

Susana Torío López. Facultad de Ciencias de Formación del Profesorado y Educación. Universidad de Oviedo. C/ Aniceto Sela s/n. 33005 Oviedo. Spain Teléfono: (+34) 985102883

Correo electrónico/e-mail:

bermudezteresa@uniovi.es,storio@uniovi.es

Fecha de recepción del artículo/

reveived date: 15.IV.2010

Fecha de revisión del artículo/

reviewed date: 26.IV.2010

Fecha de aceptación final/

accepted date: 9.II.2011

\section{Notes}

${ }^{1}$ For more information please see González, Macías and García (2002). That article contains thoughts on how to avoid that students of the educational system who are ill and hospitalized miss out on class and fall behind in their Studies. It also has suggestions on how these students may be efficiently assisted by educational actions. To the same effect, a wide bibliography regarding Hospital Pedagogy has also been included.

\section{COMO CITAR ESTE ARTÍCULO/ HOW TO CITE THE ARTICLE:}

Bermudez Rey, M.T. y Torio Lopez, S. (2012). Educacion informal y ocio juvenil. La percepcion de las familias ante la animacion hospitalaria: estudio realizado en el Hospital Materno - Infantil de Oviedo. Pedagogia Social. Revista Interuniversitaria, 20, pp. 223-242.

Bermudez Rey, M.T. \& Torio Lopez, S. (2012). Familys' Perception of Hospital Animation: A case study carried out at Hospital Materno-Infantil in Oviedo (Spain). Pedagogia Social. Revista Interuniversitaria, 20, pp. 223-242 